\title{
Teaching and Learning Conference Convenes in Portland, Oregon
}

\author{
Heidi Souerwine, Director, Meetings and Events
}

T he 13th APSA Teaching and Learning Conference (TLC) was held February 12-14, 2016, at the Marriott Portland Downtown Waterfront Hotel in Portland, Oregon. This year's program committee organized a dynamic program of sessions and workshops around the theme "Rethinking the Way We Teach: High-Impact Methods in the Classroom," focusing on effective practices and innovative methodologies for the political science classroom.

\section{PRE-CONFERENCE WORKSHOP}

The conference was preceded by a packed complimentary morning pre-conference short course "Core Knowledge and Assessment Strategies in Advanced Placement and Introductory University Courses on US and Comparative Government" sponsored by the APSA Committee on Teaching and Learning. The course explored the alignment and assessment of core knowledge in AP and university introductory government courses.

\section{KEYNOTE ADDRESS}

The program opened with the keynote address presented by C. Edward Watson. $\mathrm{He}$ is the director of the Center for Teaching and Learning at the University of Georgia where he leads university efforts associated with faculty development, TA development, learning technologies, media and production services, classroom support

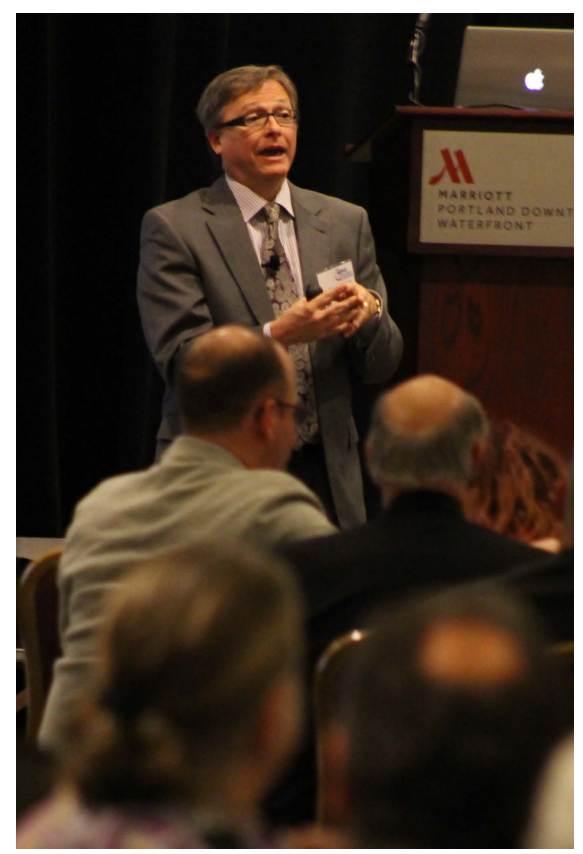

C. Edward Watson, director, Center for Teaching \& Learning, University of Georgia, delivers the 2016 keynote address.

and learning spaces, and the scholarship of teaching and learning. Watson spoke on future challenges in the classroom affecting higher education, including rising costs, student debt, assessment and accountability, Massive Open Online Courses (MOOCs), changing student populations, and more. This interactive keynote examined the most compelling trends in higher education today and paired them with things we empirically know about learning and cognition. The audience was asked to consider what teaching and learning in higher education will look like in 2020; to consider how to create a vision for the future, grounded in learning theory and the realities of higher education; and to answer the question: what is the future you want to make?

\section{AWARDS}

The keynote concluded with an awards presentation by APSA President Jennifer Hochschild and APSA Executive Director Steven Rathgeb Smith.

The Michael Brintnall Teaching and Learning Award supports faculty attendance at the APSA Teaching and Learning Conference, covering the costs of registration for the Teaching and Learning Conference, as well as a one-year complimentary APSA membership.

APSA is pleased to congratulate the 2016 award recipient William Jennings, University of Tennessee. Jennings is recognized by his colleagues at the University of Tennessee (UT) as a master educator and gifted classroom teacher. Jennings is an integral part of their undergraduate program, where he has been a lecturer since the fall of 2003. He is praised by students and colleagues alike for the quality of his lecturers, his enthusiasm for his subject and the teaching profession, and his concern for students. He is also a past

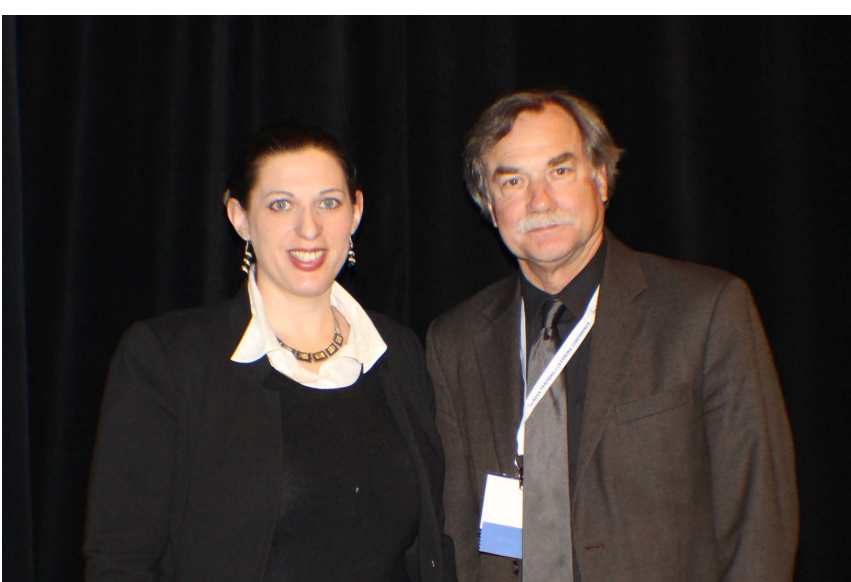

Amanda Rosen, Webster University, receives the CQ Press Award for Teaching Innovation from Steven Rathgeb Smith.

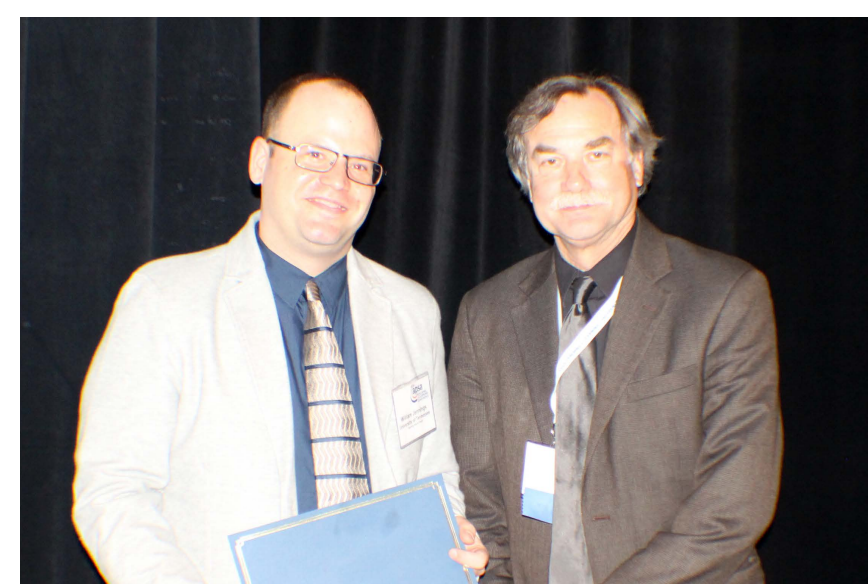

William Jennings, University of Tennessee, receives the Michael Brintnall Teaching \& Learning Award. 


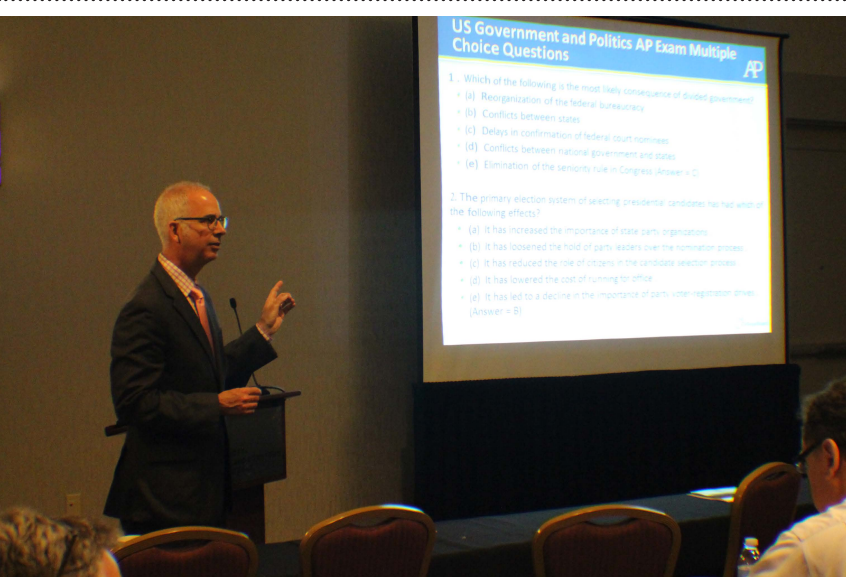

Stephen S. Meinhold, University of North Carolina, Wilmington, speaks during the pre-conference short course.

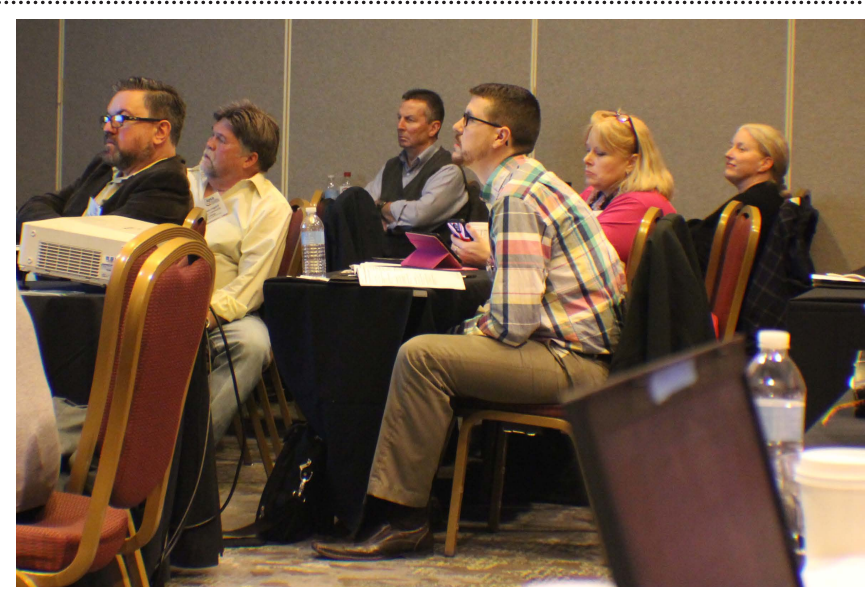

A full room of attendees listens during the morning workshop on AP and introductory government courses. winner of multiple teaching awards at UT, including the University of Tennessee's College of Arts and Sciences Lecture Excellence Teaching Award in 2012. Jennings has participated in the APSA Teaching and Learning Conference since 2006 and has presented two papers, in 2007 and in 2011.

The CQ Press Award for Teaching Innovation is sponsored by CQ Press, an imprint of Sage Publications, to recognize a political scientist who has developed an effective new approach to teaching in political science. The award honors a wide range of new directions in teaching, such as the creation of an innovative course syllabus or using a new multimedia approach in the classroom.

APSA is pleased to congratulate the 2016 award recipient, Amanda Rosen, Webster University. Rosen is recognized by her colleagues for being a true classroom innovator at the forefront in the academic literature on the use of games and simulations in the classroom to teach a wide range of subjects as well as the classroom itself. It is clear that she has a knack for creating games, exercises, and simulations that engage students and help them learn challenging material. Rosen has also found an innovative way of teaching research methods that excites and engages students. Her "Best Breakfast in Town Project" incorporates both group and individual components and takes students from the first stage of reviewing the existing literature on the subject through the research design process. She has presented on this project at the APSA Annual Meeting, has blogged about it on the Active Learning in Political Science (ALPS) blog, and discussed it in a coauthored paper at the conference.

\section{MEETING FORMAT}

At the conference, papers are presented in a collaborative working group environment,

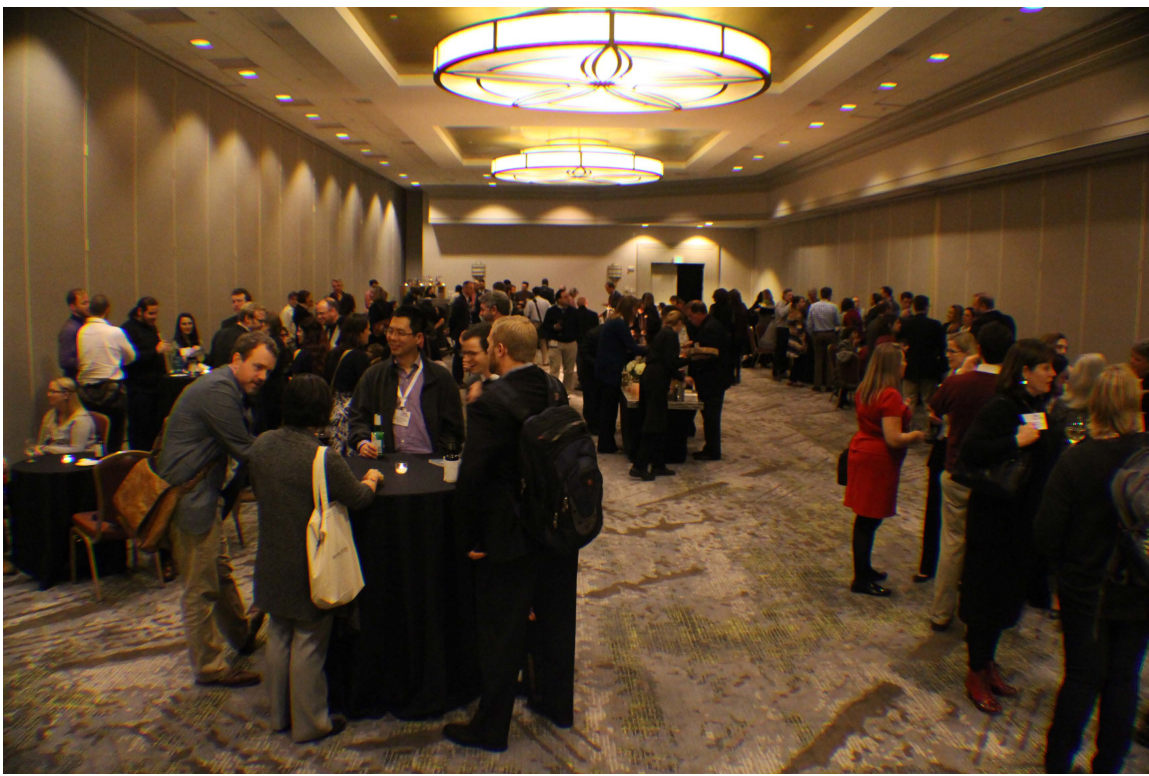

Attendees for the 2016 Teaching \& Learning Conference gather during the opening reception to catch up and connect with one another. in which the participants in a theme learn about and discuss each other's research for the duration of the conference. This working group model has proven to be highly effective at enhancing the instructional effectiveness and scholarly productivity of conference attendees.

This year sessions were organized into ten content tracks and two dedicated professional development workshop time slots, in which attendees presented research on pedagogy and discussed best practices for engaging students and training them to think critically, write effectively, and evaluate, consume, and generate knowledge of political science successfully, integrating both digital techniques and traditional methods. The program committee spent a great deal of time debating the important trends in the discipline and

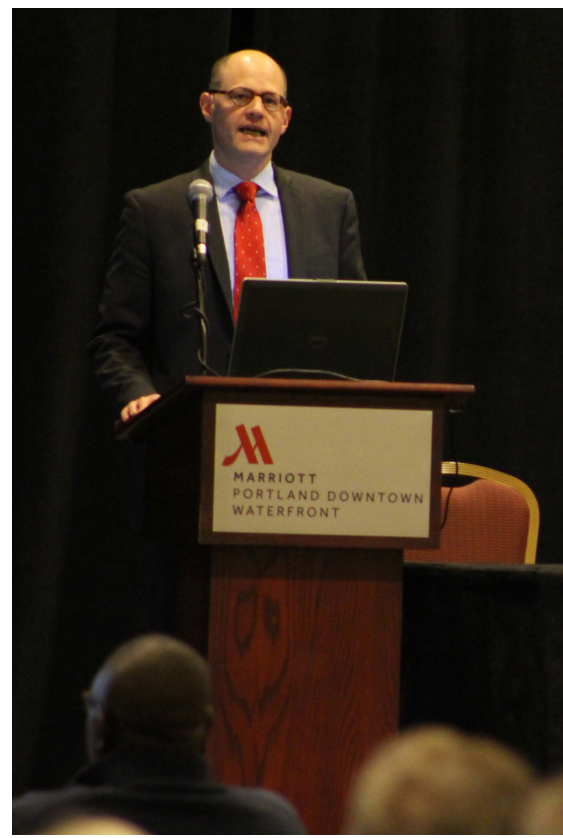

Andrew Seligsohn, president, Campus Compact, delivers the first plenary lecture. 


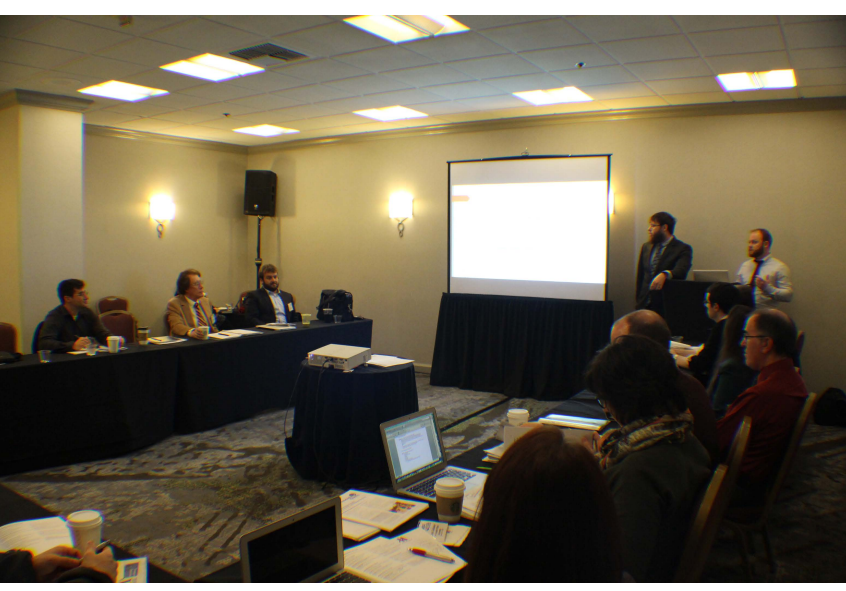

Presenters Caleb Miller (left) and Jake Eschenburg (right), University of California, Santa Barbara, present their paper "Graduate Student Apprentices: Are Teaching Assistantships Effective 'On-the-Job' Training?" on Saturday. (Coauthor Colin Kuehl is seated third from the right.)

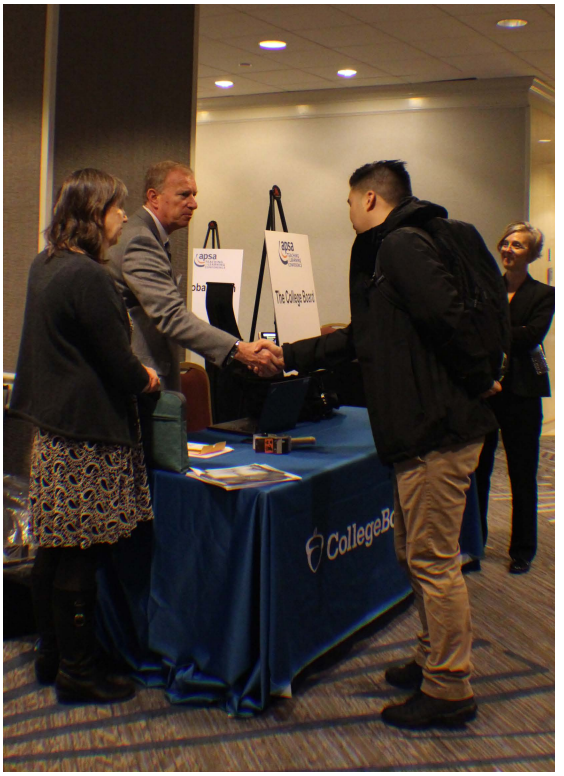

Bill Tinkler, College Board, stands at the College Board's exhibit table and greets a short course attendee.

crafted new and revised tracks to focus attendees on key challenges in the classroom. The 2016 tracks were Civic Engagement Across the Disciplines and Across the Campus; Core Curriculum/General Education; The Inclusive Classroom; Integrating Technology into the Classroom; Online Learning; Simulations and Games: Applications; Simulations and Games: Evaluation; Teaching How To Teach; Teaching Democratic Theory Today; and Teaching Research Literacy.

For the first time, the conference also included a Plenary Lecture on the second day, delivered by Andrew Seligsohn, the president of Campus Compact, a national

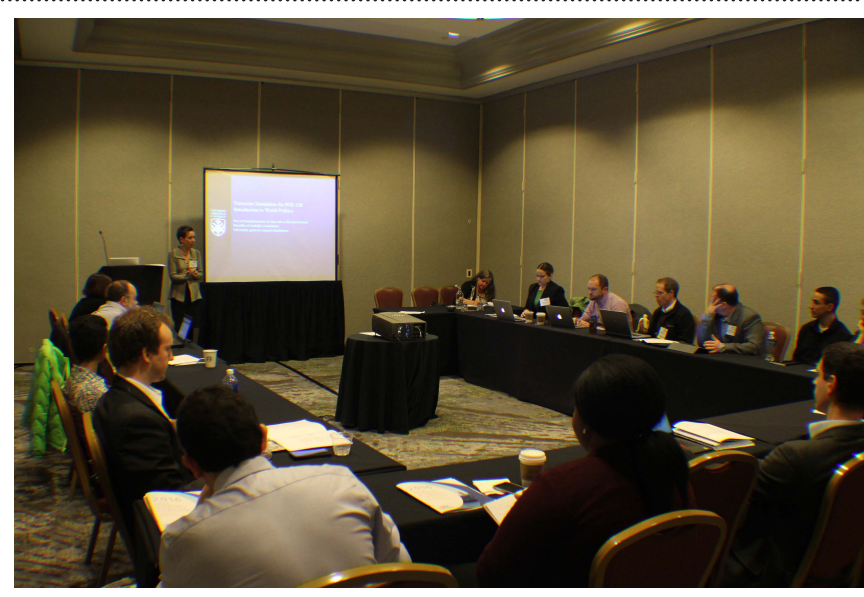

Gretchen Knudson Gee, Northern Arizona University, presents her paper "Scaling Up Simulations for Large, Multi-section Courses" on Saturday for the Simulations and Games: Evaluation track.

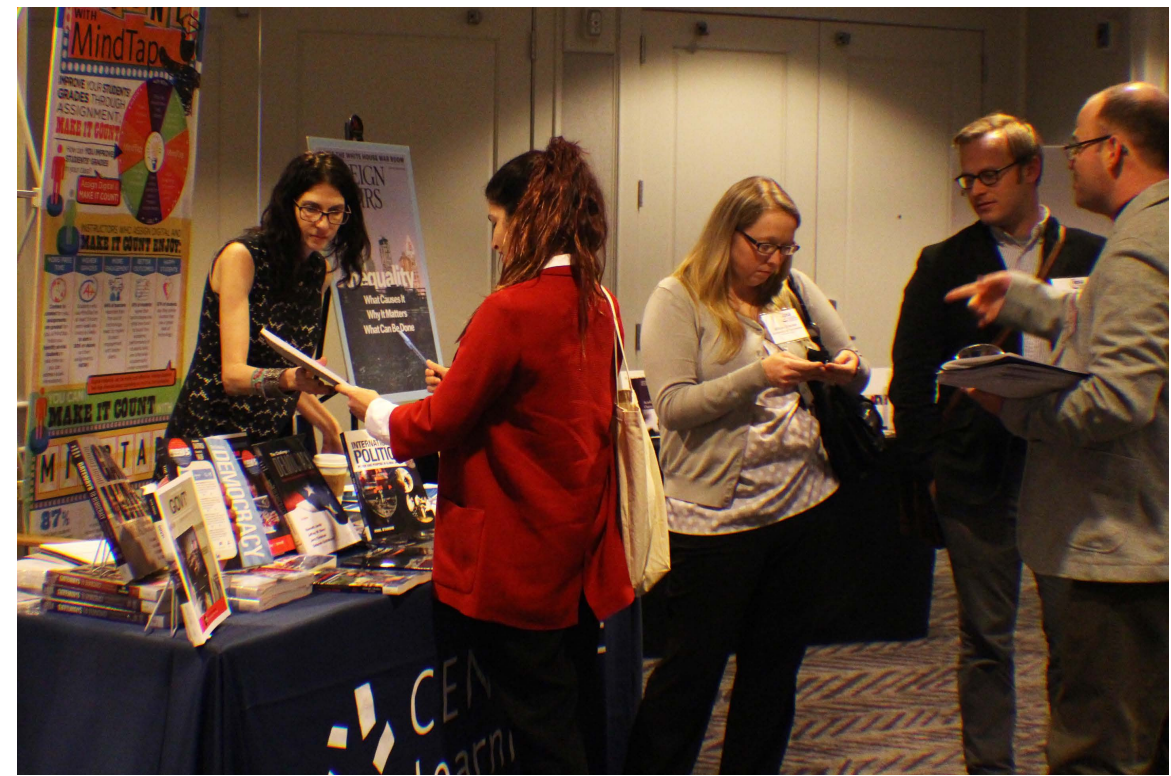

Valeria Hartman (left), Cengage Learning, assists a curious attendee. Cengage Learning was the Gold Sponsor for the conference, and their colorful display attracted attention and stimulated conversations in the exhibit area.

coalition of nearly 1,100 colleges and universities committed to the public purposes of higher education. Seligsohn encouraged attendees to think about ways to develop students' citizenship skills and forge effective community partnerships. He closed his remarks with recommendations for enhancing public engagement among students.

Looking ahead, the research presented and the ideas generated and shared at the 2016 APSA Teaching and Learning Conference provide the unique opportunity to stimulate and create conversation in the discipline about pedagogical research and innovations.
Track summaries of the 2016 Teaching and Learning Conference will be available in the July 2016 issue of PS: Political Science \& Politics. We look forward to what the tracks' authors put together!

\section{TEACHING \& LEARNING \\ CONFERENCE PROGRAM COMMITTEE}

Audrey Haynes, University of Georgia Chera LaForge, Indiana University East Sara Moats, Florida International

\section{University}

Chad Raymond, Salve Regina University

Dick Simpson, University of Illinois at Chicago 